\title{
NON-DESTRUCTIVE INVESTIGATION ON SMALL EARTH DAMS USING GEOPHYSICAL METHODS: MULTICHANNEL ANALYSIS OF SURFACE WAVES (MASW) AND S-WAVE SEISMIC REFRACTION TOMOGRAPHY
}

\author{
Leonides Guireli Netto1', Otavio Coaracy Brasil Gandolfo1, Walter Malagutti Filho² and João Carlos Dourado²
}

\begin{abstract}
The application of non-destructive methods of investigation in dams, such as refractive seismic method and Multichannel Analysis of Surface Waves (MASW) are increasingly effective from the point of choosing the best dam site, as well as in the phases of construction and maintenance of the structure. The objective of the research was to apply geophysical methods in the structure of the dam to detect the internal flow of fluids, the presence of voids, find possible fracture zones and variations in the level of saturation of the massif, characteristics related to permeability and directly linked to the stability of the dam. In this way, geophysical methods have proved to be excellent tools, because, unlike instrumentation traditionally used in this type of monitoring, such as piezometers and water level indicators, they can cover a large study area quickly. This paper aims to present the results of the correlation between the MASW method and the Swave seismic refraction method in two small earth dams in the countryside of the State of São Paulo, Brazil, more precisely in the cities of Cordeirópolis and Ipeúna. The main goal was to obtain the depths of the rocky top and the saturated/unsaturated zone of the earth dams using seismic tests under conditions of lack of information about the construction of the dam. The application of geophysical methods in dams that do not previously have important information (presence of drainage blanket, vertical/horizontal filters, for example) proves to be a very interesting non-destructive investigation technique.
\end{abstract}

Keywords: geophysics in dams, MASW, seismic refraction, dam investigation.

RESUMO. A aplicação de métodos não destrutivos de investigação em barragens, como o método da sísmica de refração e a análise multicanal de ondas de superfície (MASW), são cada vez mais eficazes desde a fase de escolha do melhor local para a instalação da barragem, bem como nas fases da construção e manutenção da estrutura. $O$ objetivo da pesquisa foi aplicar métodos geofísicos na estrutura da barragem para detectar o fluxo interno de fluidos, a presença de vazios, encontrar possíveis zonas de fratura e variações no nível de saturação do maciço, características relacionadas à permeabilidade e diretamente ligadas à estabilidade da barragem. Desta forma, os métodos geofísicos se mostraram como excelentes ferramentas, excelentes ferramentas, pois puderam cobrir uma grande área de estudo com rapidez, diferentemente da tradicional instrumentação utilizada neste tipo de monitoramento, como piezômetros e indicadores do nível d'água. Este trabalho tem como objetivo apresentar os resultados da correlação entre o método MASW e o método sísmico de refração com ondas $\mathrm{S}$ em duas pequenas barragens de terra no interior do Estado de São Paulo, mais precisamente nas cidades de Cordeirópolis e Ipeúna. 0 objetivo principal foi o de obter as profundidades do topo rochoso e da zona saturada/insaturada das barragens de terra fazendo uso de ensaios sísmicos em condições de ausência de informações a respeito da construção do barramento. A aplicação de métodos geofísicos em barragens que não possuem previamente informações importantes (presença de tapete drenante, filtros verticais/horizontais, por exemplo) mostra-se como uma técnica de investigação não destrutiva bastante interessante.

Palavras-chave: geofísica em barragens, MASW, sísmica de refração, investigação em barragens.

Corresponding author: Leonides Guireli Netto

${ }^{1}$ Instituto de Pesquisas Tecnológicas - IPT, São Paulo, SP, Brazil - E-mails: leonidesnetto@ipt.br, gandolfo@ipt.br

2Universidade Estadual Paulista - UNESP, Rio Claro, SP, Brazil - E-mails: malaguti@rc.unesp.br, jdourado@rc.unesp.br 


\section{INTRODUCTION}

The development and use of dams began thousands of years ago. In Brazil, according to data from the Agência Nacional de Águas (ANA - National Water Agency) as of 2013, 13,529 dams were registered throughout the country. Among these, large dams, which drew attention due to the recent accidents, are only 371 . Therefore, the great majority of the national dams are of medium or small size.

The first projects of dams were constructed empirically, that is, without great engineering techniques and little scientific knowledge, with the intention of damming a material, initially water, through the construction of a blockage in transversal position to the main flow of a river, mainly with material near the construction site, creating an artificial reservoir for water accumulation. With the advancement of knowledge on Dams Engineering, the dams reached larger sizes and the uses became varied, such as dams for electric power generation (Brazil's main energy source), embankments or dams for industrial waste storage, fish farming, leisure and mining tailings dams, added to the classic and pioneering use for irrigation (Duarte, 2008).

Currently, dams can be classified in different ways, depending on the type of retention structure used (land, rockfill, gravity and mixed, for example), depending on the generation system (base or tip generation plants, reversible mills or tides) and materials used in its construction processes (geomaterials, concrete, synthetic materials and civil construction steel). Due to lower costs, simpler construction techniques and large soil presence, earth dams are the most common type of small dams (Cullen, 1964). According to data from Bulletin 99 of the International Commission on Large Dams (ICOLD), due to the ease of construction and use of less robust techniques, landfill dams account for approximately $45 \%$ of the accidents due to foundation problems, such as piping of the dam body (28\%) or erosion of the foundation (17\%).

In Brazil, recent cases of tailings dam rupture have gained prominence due to natural, social and economic disasters. In 2015, a tailings dam in Mariana - Minas Gerais from the Samarco mining company burst, dumping 62 million $\mathrm{m}^{3}$ of tailings in areas as far as $100 \mathrm{~km}$ from the dam (IBAMA, 2015). In the beginning of 2019, an iron ore tailings dam of the mining company Vale burst in Brumadinho Minas Gerais, dumping 12 million $\mathrm{m}^{3}$, causing hundreds of deaths and environmental losses in an area of 2.6 million $\mathrm{m}^{2}$.

Despite being a minority (approximately ten thousand dams of the total of two hundred thousand), the medium and large dams have the largest contribution of resources for geotechnical research and the elaboration of technical projects. For that reason, a more detailed study of the small dams is mandatory, not only because they are more common, but also because they are easier to study and the knowledge acquired can also be used in larger dams.

Another alarming problem refers to limited data on the conditions of Brazil's dams. The National Dams Safety Policy (PNSB), published in 2010, suffered from a lack of data in its latest issue, as the following: dam height, potential damage rating and reservoir capacity. The data about these topics were not contained in several reports sent to the ANA. There is a clear need for investments in techniques that could help in the management of dam safety levels and, more than that, to employ methods that can help in the investigation of the conditions of the dams, in a scenario which there isn't any previous information since many of the dams are abandoned.

The geophysical methods, for instance, can be a tool with a low-cost benefit ratio, concerning both installation and construction of the dam. It can also be applied in the phase of maintenance and monitoring of the safety level of the dam through time, since the integration of different geophysical methods can assist in the detection of internal flows and/or weaknesses developing or formed in the dam structure, for example.

The seismic study presented here is only part of a larger project for the use of geophysical methods in small-scale dams, other methods such as electrical tomography (Camarero \& Moreira, 2017) and self-potential (Guireli Netto et al., 2020) have already been performed in dams. The objective was to perform two non-destructive geophysical investigation methods that allowed to better identify the physical characteristics of the materials that compose the dam body, as well as to identify the bedrock under which the dam was constructed, since these data were not available.

This paper targets the use of MASW (Multichannel Analysis of Surface Waves) and S-wave seismic refraction, making a comparison between both methods of analysis of the behavior of the shear wave in subsurface and the consequence on the physical integrity of two land dams located in the cities of Ipeúna and Cordeirópolis, both in the interior of the State of São Paulo, Brazil.

\section{THE PHYSICAL INTEGRITY OF DAMS AND THE AID OF GEOPHYSICAL METHODS}

Until the mid-nineteenth century, the construction of dams had an empirical basis, taking into account a technique that resulted in cross sections of high volumes, since they followed the idea of reservoir containment by the dam mass (Bretas et al., 2010).

Almost at the end of the nineteenth century, the first works in this area were published, being the first the famous 
"A Manual of Applied Mechanics" by Rankine \& Millar (1898). However, the focus on intensifying dam safety development occurred only in 1979, during the International Commission on Large Dams in New Delhi (ICOLD, 1995). In other words, dam safety is a relatively recent issue that has been developing since the last quarter of the twentieth century. According to Lou (1981), the reasons that can lead to the rupture of a dam can be divided into two groups: causes of human and non-humanorigin.

The first group includes deficiencies and errors in the construction and/or design and improper location of the dam. The geophysical methods can help in the characterization of the lithologies present in the area, seeking to assist in choosing the most suitable location for the construction of the dam, but this is not the focus of this investigation.

This study aims to put a spotlight on the second group, which addresses problems in landfill dams, such as overtopping, internal erosion in the dam body (piping) and/or foundations problems, landslides and earthquakes.

According to data from the 2014 Dam Safety Report issued by the National Water Agency (ANA), the main causes of ruptures of earth dams are: events of internal erosion in the body of the dam (piping), instability of slopes and overtopping. The latter occurs when the dammed water level is higher than the ridge level, that is, it overflows. Generally, the result is the collapse of the dam body. The instability of the slope can be generated by several factors varying according to the material used in the construction of the dam. When it comes to earth dams, poor compaction of the material can cause increased infiltration and elevation of the water table, compromising the structure of the dam.

The regressive erosion process from downstream to upstream into the body of an earth dam can result in its rupture, developing a pipe capable of carrying soil particles by the mass, resulting in an unrestrained flow. In homogeneous dams, (only compacted soil without the presence of an impermeable central core) this type of process is more recurrent.

Recent accidents in dams draw attention to the need for investment in further studies, in addition to the development of new dam monitoring and inspection techniques. The use of associated geophysical methods, as proposed by the present study, can be an alternative that will bring positive results, such as the use of the self-potential (classically used in dams), electrical and seismic methods. Therefore, applied geophysics is shown as a non-destructive method of evaluating the physical integrity of dams, both in the construction phase of the work and also as a mechanism to follow the development of the dam during its lifetime, certainly increasing the dam's levels of security.

\section{APPLICATION OF THE MASW AND SEISMIC REFRACTION METHODS IN DAMS}

The seismic refraction method is much more consolidated in the applied geophysics community than the Multichannel Analysis of Surface Waves (MASW) method. However, the use of the S-wave in the refraction method is not commonly applied. The application of both methods presented in this study in dams is a little more difficult to find, making it interesting to disseminate the results. Works involving the use of seismic refraction applied to dams are mostly related to the study of the depth of the dam foundation, as shown by Dutta (1984).

Later, Herzig (2003) presented the application of shallow seismic to obtain subsurface structural information that subsidized a dam construction project. On the aforementioned report, the possibility of applying seismic methods at both the phase of investigation, prior to dam construction, and during the maintenance and inspection phases was made clear.

Another important work was developed by Teixeira (2013), concerning the application of various geophysical methods in dams, such as electrical tomography, ground penetrating radar (GPR) and seismic refraction methods, seeking to analyze the physical integrity of dams.

As for the object being discussed on this paper, the MASW method has been increasingly implemented and accepted by the geophysics community over the years, a good part of this study is mainly applied to understanding the material compaction and variations of the thickness of the lithological layers, as shown by the works of Karray et al. (2010), Eikmeier (2014) and Guireli Netto et al. (2019).

\section{GEOGRAPHICAL AND GEOLOGICAL LOCATION OF THE STUDY AREA}

The area subject to this study is located in the interior of the State of São Paulo in Brazil, in the cities of Cordeirópolis and Ipeúna, and it includes two small earth dams. The first one is 69 meters long and approximately 6 meters wide in ridge, being used for irrigation of sugarcane crops; the second one is 86 meters long and approximately 5 meters wide and is used for fish farming (Fig. 1).

Both dams do not have the construction projects. However, it is believed that the dams were constructed by compaction of alteration soils existing near the construction sites, without the presence of vertical or horizontal filters in their bodies. This type of construction, quite simple and requiring relatively low investment has been mainly used in Brazil for small dams. 


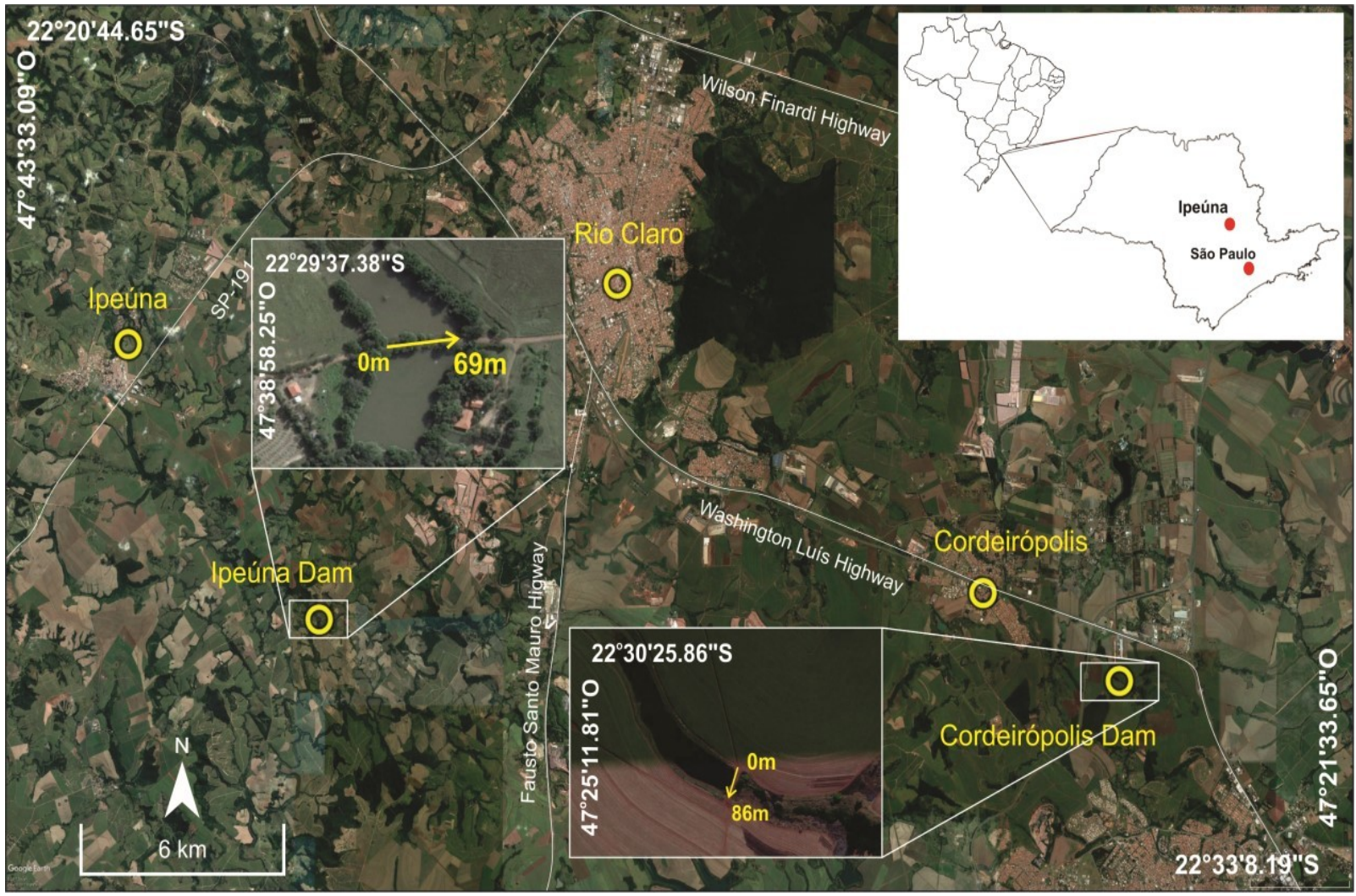

Figure 1 - Location of the study areas and arrangement of the geophysical acquisition lines. Source: changed from Guireli Netto et al. (2017); modified from GOOGLE EARTH (2019).

The reasons for choosing these dams were not random, they had already performed geophysical surveys in their areas: electrical tomography (Camarero \& Moreira, 2017) and self-potential (SP) (Guireli Netto et al., 2020). The electrical one indicated both a possible internal erosion (piping) event in the dam located in Cordeirópolis and a process of water saturation/infiltration in the structure of the dam located in Ipeúna. The knowledge of these data facilitates the interpretation of the seismic refraction data. Another good point is that, even though they have the same construction technique (a homogeneous dam consisting of a single compacted material), the Cordeirópolis and Ipeúna dams have local geology with different characteristics (degree of compaction and different electrical resistivities, for instance), which could result in distinct S-wave velocities. Such set of characteristics would favor the application of the method on the dams.

The study area is geologically inserted in the Paraná Sedimentary Basin and has a sedimentary fill composed of siliciclastic materials with intrusion of a basaltic lava flow, quite expressive throughout the region of the study. The following geological formations of the Paraná Sedimentary Basin occur in the region: Itarare Group, Tatuí, Irati, Corumbataí, Pirambóia, Serra Geral and
Botucatu Formations. However, this work will focus only on the Itararé Group and the Serra Geral Formation, which are lithostratigraphic units present in the Cordeirópolis and Ipeúna areas, respectively.

The Serra Geral Formation in the area is represented by a clayey lateritic soil with a reddish-brown coloration, characteristic of the alteration of basic rocks. The altered basalt blocks occur frequently in the region and around the dam of the city of Cordeirópolis - São Paulo (Fig. 2A). Geological mapping in the region indicates that rivers are running over basalt spills (Morenghi, 2007).

On the other hand, the Itarare Group in the region of the dam located in Ipeúna - São Paulo has a different lithology than the Cordeirópolis area. In this case, outcrops are formed composed of clayey diamictites with granules up to $4 \mathrm{~cm}$, as well as light gray colored siltstones (Fig. 2B). The outcrops found in the region of the Ipeúna dam (clayey diamictites with granules of different dimensions), are typical of the influence of glacial processes. According to Zaine (1994), the sediments of the Itararé Group are found in the basal unit of the permo-carboniferous sequence of the Paraná Basin, outcropping at the base of the stratigraphic column in the bottom areas of river valleys in the region of the study area. 


\section{MATERIALS AND METHODS}

The availability of the dam construction project would be very positive and could bring important insight in the interpretation of the data, such as the precise location of the spillways, the existence or not of waterproofing material in the central part of the dam body, lithological variations in the composition of the chosen material and the presence or absence of vertical and/or horizontal filters, for example.

However, dam design data were not available, which made the interpretation process much more difficult. It is worth mentioning that with the construction project and prior knowledge of the material of the dam body it would have been possible to carry out simulations in a dedicated software in order to have an idea of the model to be found in the field.

The geophysical data acquisition performed in this work utilized the following seismic methods: Multichannel Analysis of Surface Waves - MASW and S-wave seismic refraction at the crest of the dams.

The use of seismic methods prior to the construction of a dam is interesting, since it is a work of great impact and requires high levels of safety. The precise determination of the dynamic elastic parameters of the massif (since the reservoir is not static) $(\mathrm{P})$ and shear $(\mathrm{S})$ modulus in this case are necessary and possible to obtain through the propagation velocities of the compressional $(\mathrm{P})$ and shear (S) seismic waves (Taioli, 1999; Pasquet et al., 2015).

Both methods provide the S-wave velocity mapping in depth. The process of data acquisition is very similar among the methods (Gandolfo, 2011) (Fig. 3). Thus, the joint use of the methods become interesting since the same arrangement is used. Furthermore, the comparison of both methods increases the safety in making affirmations about the depth of the lithological contacts, for example.

\section{Multichannel Analysis of Surface Waves (MASW)}

The MASW (Multichannel Analysis of Surface Waves) method has as principle the extraction of a dispersion curve from a double Fourier transformation of multichannel recordings. Those recordings receive the surface waves generated by a seismic source (Xia et al., 2000). The method is performed through the spectral analysis of the surface waves generated by a seismic source, generating a layer model in terms of Vs (shear wave velocity) (Turesson, 2007).
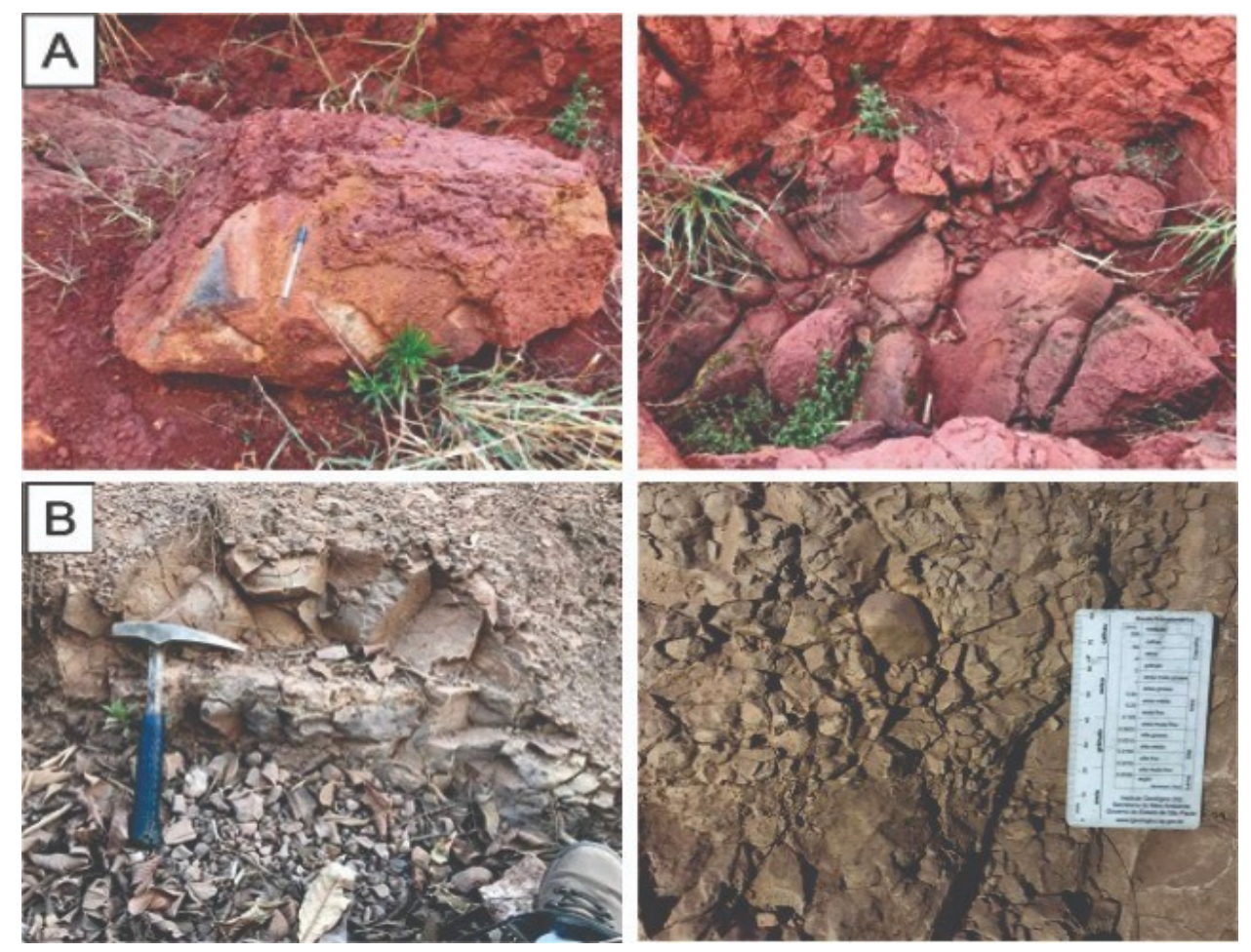

Figure 2 - A) Outcropping of altered basalt blocks, typical of the Serra Geral Formation; B) Outflow of diamictite, characteristic of the Itararé Group near the Ipeúna dam, with granule detail. Source: Guireli Netto et al. (2017). 


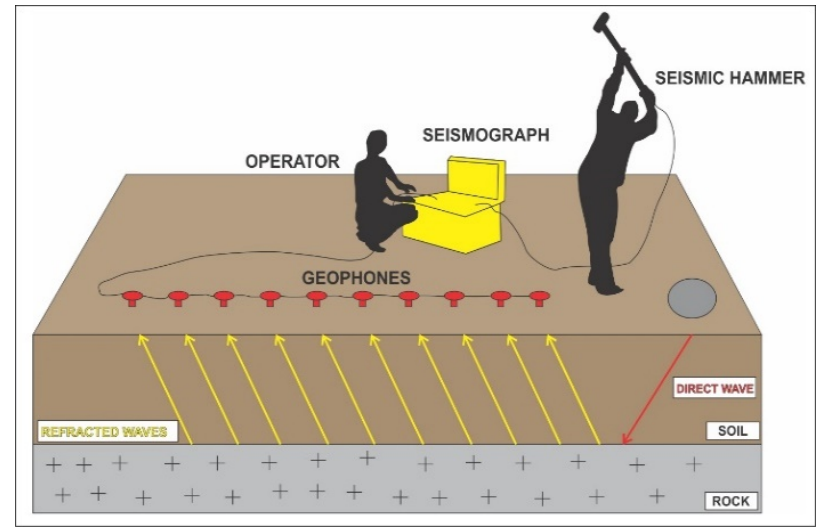

Figure 3 - Acquisition scheme of the seismic tests of this study, both methods have similar arrangements, changing only the shooting region and seismic wave generation.

It is advisable to use the MASW method together with other methods, especially other seismic methods: crosshole geophysical testing and, as shown by this work, refractive seismic method, aiming to operate with shallow areas (up to 10 meters) due to the frequencies used by the method (between 4 and $50 \mathrm{~Hz}$ ). The main use of this seismic method is the characterization of alteration of soils and the evaluation of compaction techniques of soils and pavements.

The understanding of the dispersive character of surface waves in stratified media, for example in order to infer variations in the elastic properties of the subsurface, is of great importance in engineering geology, since the velocity of the S-waves is directly related to the degree of rigidity of the subsurface material and is practically insensitive to the saturation of the earthy mass. This characteristic made the use of the method in this study more interesting, since as mentioned before, the data of electroresistivity and selfpotential pointed to a possible water infiltration in the body of the dam in some points. The same applies to the study of the physical integrity of dams, considering that poorly consolidated materials would have lower values of Vs, and materials with a lower degree of alteration, such as a sound rock, would have higher values of Vs and, therefore, higher values of stiffness (Foti, 2000).

Another feature of the MASW method that was expected to be referred to is the depth of the method. Since it is a suitable method to analyze the behavior of the S-wave at shallow depths, it was expected to obtain reliable data at depths of around 10 meters. It is clear that depending on the conditions of compaction, porosity, degree of saturation and

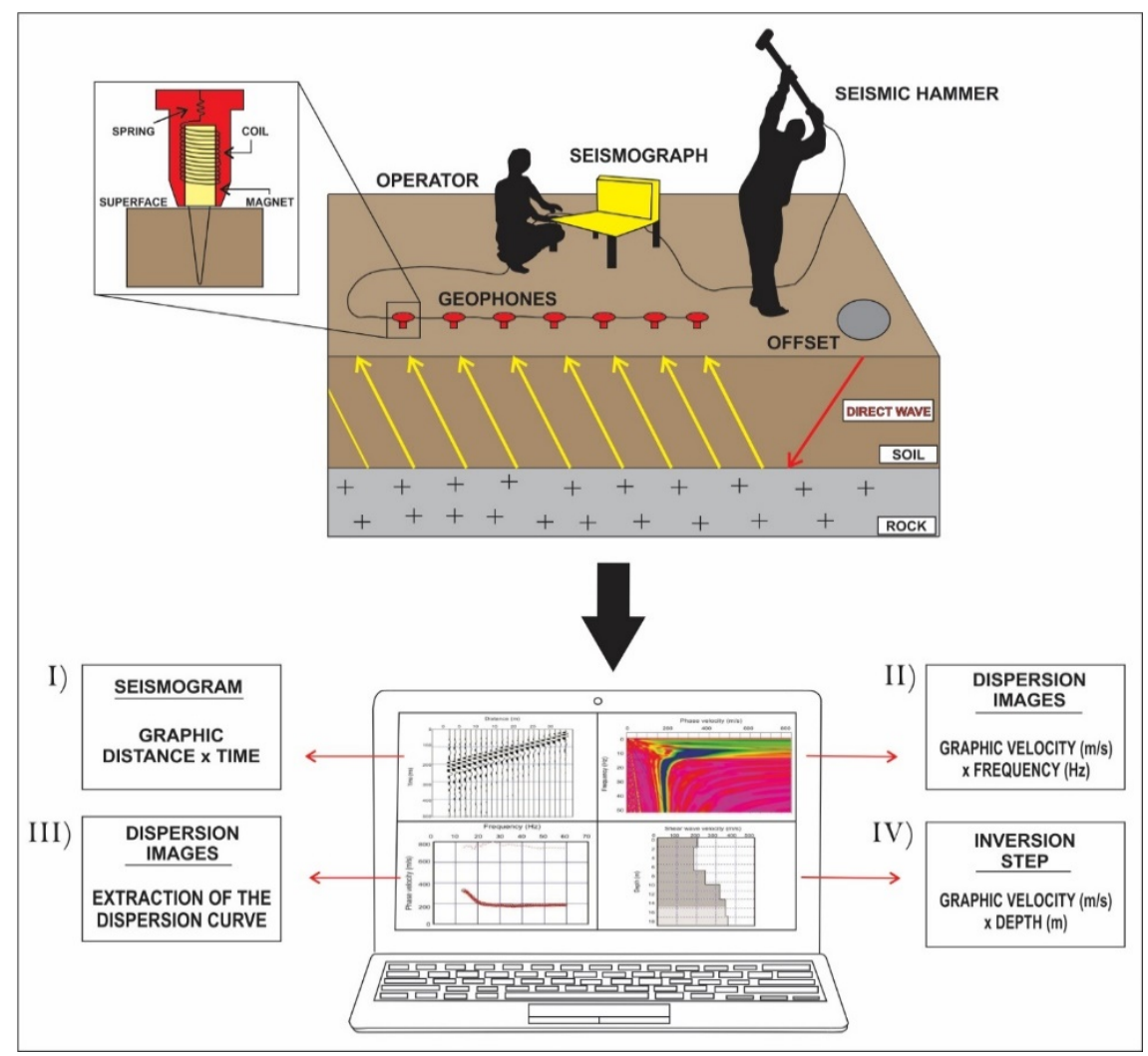

Figure 4 - Processes of the MASW method: acquisition and processing steps. 
rigidity of the material, the penetration capacity of the Swaves increase, also increasing the reach levels of the method.

The operation of the method is not very complex, being carried out in three steps: data acquisition, extraction of the dispersion curve and inversion of the dispersion curve to obtain 1D profile of S-wave velocities (Vs) (Fig. 4).

\section{Seismic refraction}

The seismic refraction method is based on the assumption that when a seismic wave encounters changes in the elastic properties of the environment it is traveling through, such as a contact between layers of distinct lithologies, part of the energy is reflected, another part is refracted and one part of the energy is absorbed by its surroundings.

The refraction of a seismic wave, therefore, occurs when the seismic wave, after encountering and transposing a layer interface with distinct elastic composition materials, begins to propagate at a different velocity than before (Seimetz, 2012).

The angle at which the seismic wave strikes the interface will also influence the direction of wave propagation. The angle between the normal to the surface and the wave radius is called the angle of incidence. However, if the incidence is normal to the interface that separates the layers, there will be no change in the direction of propagation.

The seismic refraction method using the S-wave is almost never used. However, it makes sense to use it in this study considering the objectives of this investigation (assessment of the stiffness and physical integrity of the earth dams) and that the MASW 1D / 2D test data also provides the velocities values of the S-wave in depth in the profile format.

Geophysical surveys were carried out on October 2018. The data acquisition used the same arrangement for both the S-wave seismic refraction and the MASW method, both of which were collected with the 24-channel Geode (Geometrics) seismograph (Fig. 5). The MASW method made use of $4.5 \mathrm{~Hz}$ vertical component geophones, while the refraction seismic data collection used $28 \mathrm{~Hz}$ horizontal component geophones. In both methods, the sledgehammer was used as the source of seismic waves. The seismic sledgehammer was used as a seismic wave source, since it was capable of reaching the desired depth levels in the investigation with this type of source. In addition, the seismic sledgehammer can generate the types of waves needed for the study, striking both directly on the ground and horizontally on the wooden trunk.
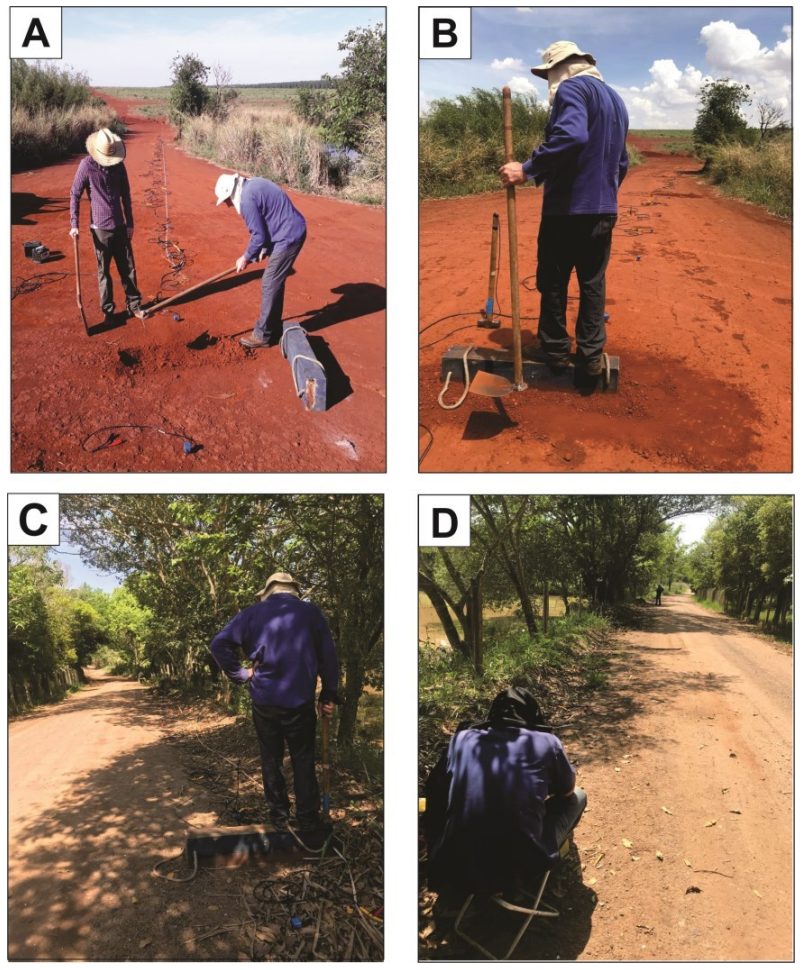

Figure 5 - A) Preparation of the S-wave source site for the seismic refraction essay; B) Arrangement and seismic data acquisition in Cordeirópolis - São Paulo; C) Seismic survey in the dam in Ipeúna São Paulo; D) Seismic data acquisition in Ipeúna - São Paulo.

On the first day of collection, seismic data were collected at the dam located in Cordeirópolis in an acquisition line 86 meters long with spacing of 2 meters between the geophones. However, it was noticed that it was difficult to record the seismic waves in the geophones farther from the source. For that reason, it was decided to use a smaller spacing between the geophones in the data acquisition in Ipeúna, performing a seismic survey line of 69 meters with spacing of 1.5 meters between the geophones interval.

For the MASW method we employed minimum offsets of $4,8,12$ and 16 meters in Cordeirópolis, while in Ipeúna the offsets were $3,6,9$ and 12 meters.

\section{RESULTS AND INTERPRETATIONS}

In order to display the results and interpretations more clearly, we will first present the results of the dam located in Cordeirópolis - São Paulo and then the data of the dam located in Ipeúna - São Paulo. After that, we will make more comments and observations comparing the results in both dams, which have distinct characteristics. 


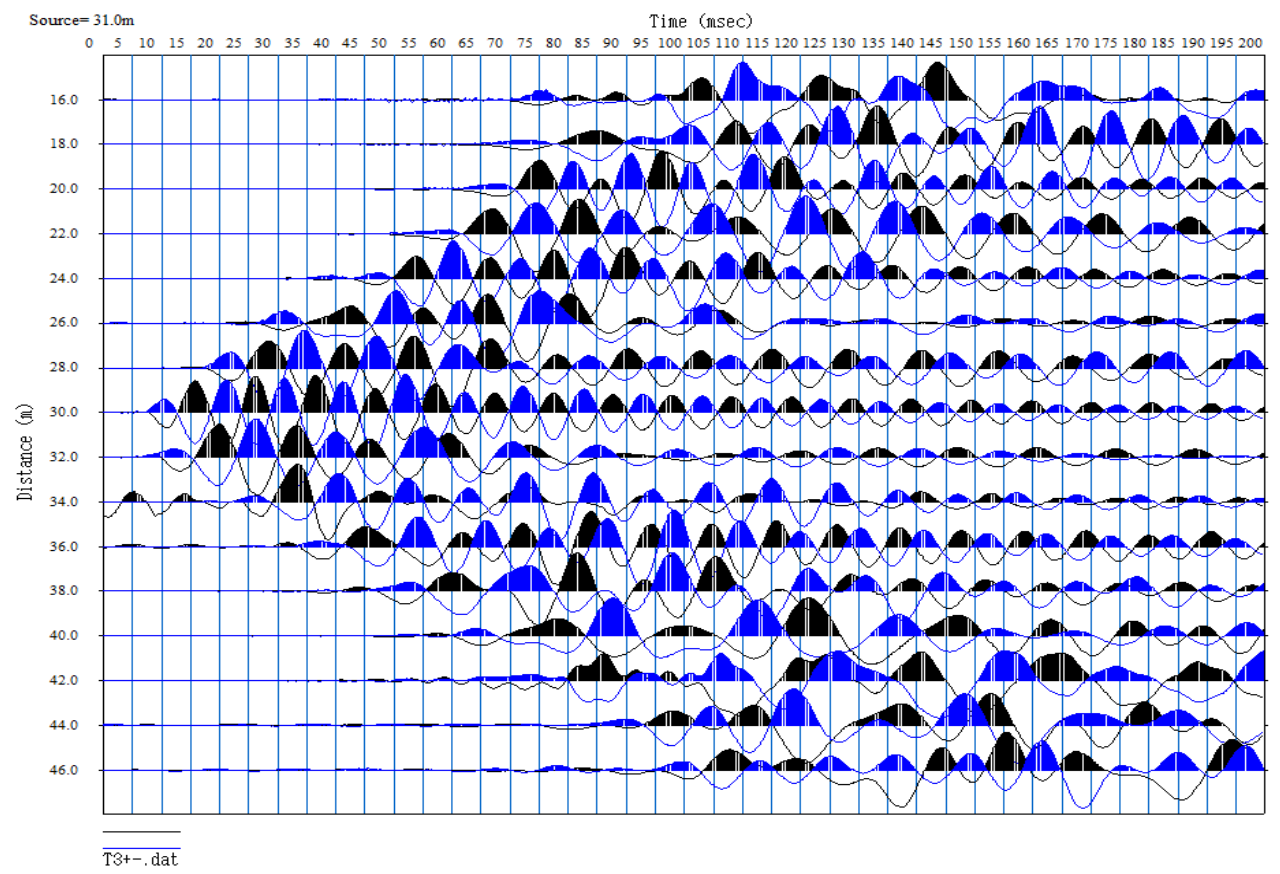

Figure 6 - Seismogram with the S-wave record obtained with the shot at the 31 meters position.

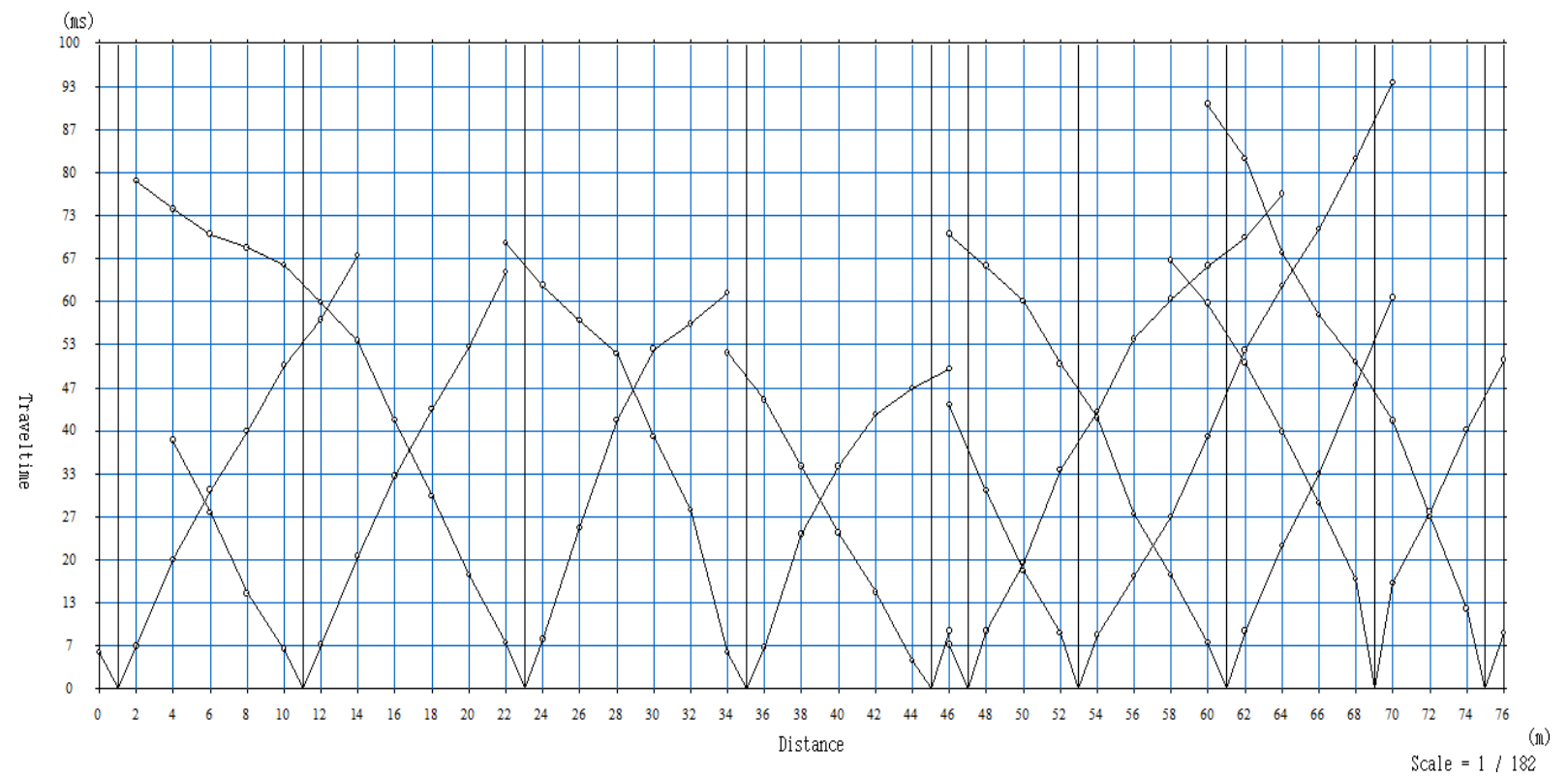

Figure 7 - Time curves $x$ distance result of the ten shots (five shots per base) performed in the line of seismic acquisition of S-wave refraction.

\section{CORDEIRÓPOLIS DAM}

The velocity of seismic wave propagation depends on the mechanical properties of the geological materials by which they are transmitted. Therefore, it was expected to find different results of propagation velocities of the S-waves on the studied dams, due to the presence of different lithologies.
The areas of study are located outside major urban centers in a rural area with low vehicle traffic. Therefore, it was understood on general terms that good quality and easily processed data was obtained, since it had only few sources that could generate noise. However, the dam structure itself, due to the movement of the reservoir water, could generate seismic waves that could hinder data acquisition. 


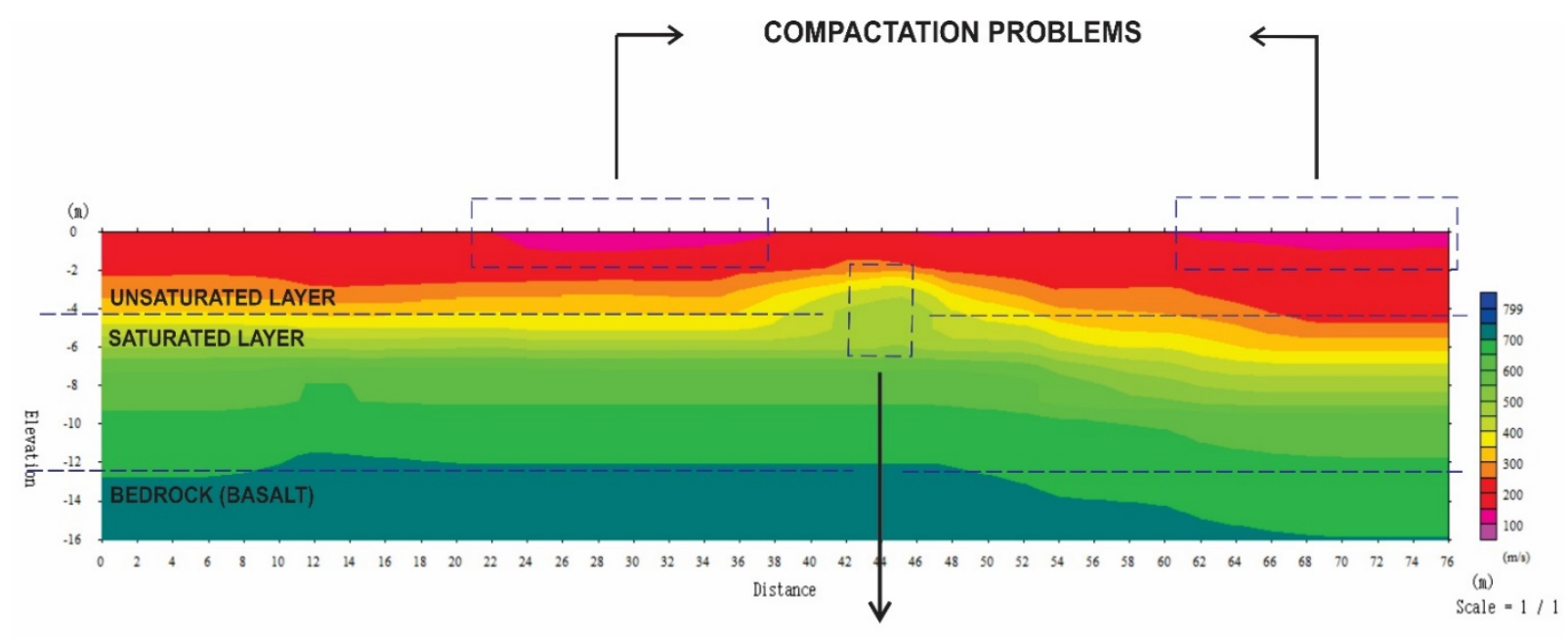

INFLUENCE OF THE SPILLWAY

Figure 8 - Section 2D modeled S-wave refraction obtained by tomographic inversion of the dam located in Cordeirópolis - São Paulo.

Figure 6 shows seismogram at the 31-meter shooting position (the center of the array), where the first breaks of the refracted waves were extracted. The acquisition of the data is made from strokes of the mallet on the ground and the data will overlap to generate the visualized seismogram. The first break picks of all seismograms resulted in the graph: time $\mathrm{x}$ distance showed in Figure 7.

In the seismogram of Figure 6, as the "strike point" (point of the seismic source - region of the hammer strikes in the ground) was in the almost central region of the arrangement, it was possible to collect data in all 24 geophones of the arrangement that constituted the seismic base, even on geophones furthest from the source; therefore, it is a reliable determination of the arrival times of

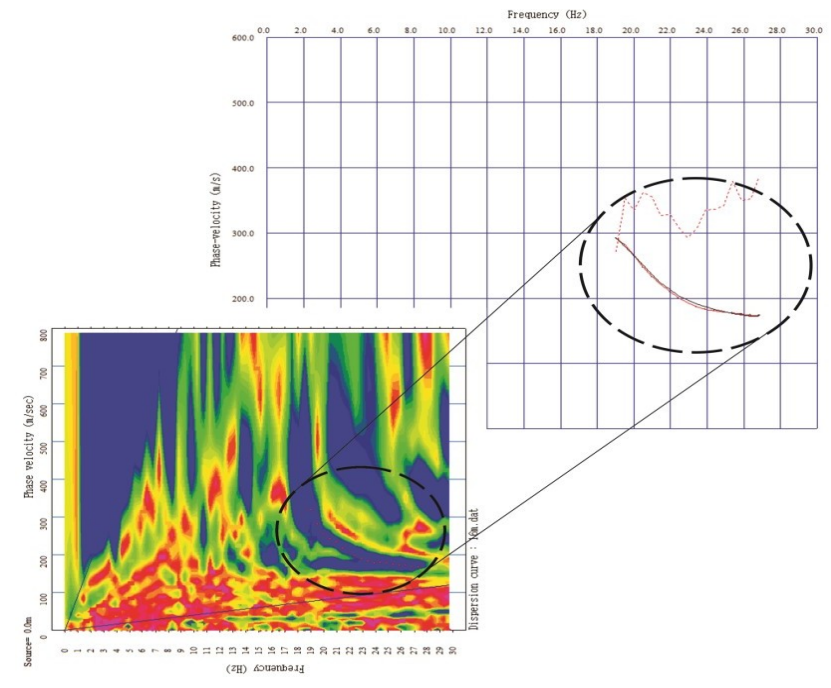

Figure 9 - Dispersion image obtained from the MASW data and the extracted dispersion curve (base 1 of the seismic line). the S-wave at these points. If this situation was not found during data acquisition in the field, in the pre-processing step, which consists of verifying the quality of the acquired data, controlling the influence of seismic noise, the ideal would be to start the data collection again, using this time an arrangement with smaller spacing between geophones. In the dam located in Ipeúna, it was noted that the seismic waves were not reaching the geophones furthest from the arrangement with spacing of $2 \mathrm{~m}$ between them, so it was decided to reduce the spacing to $1.5 \mathrm{~m}$. The signal quality has improved considerably. This condition may have occurred due to the degree of compaction and/or saturation of the dam massif.

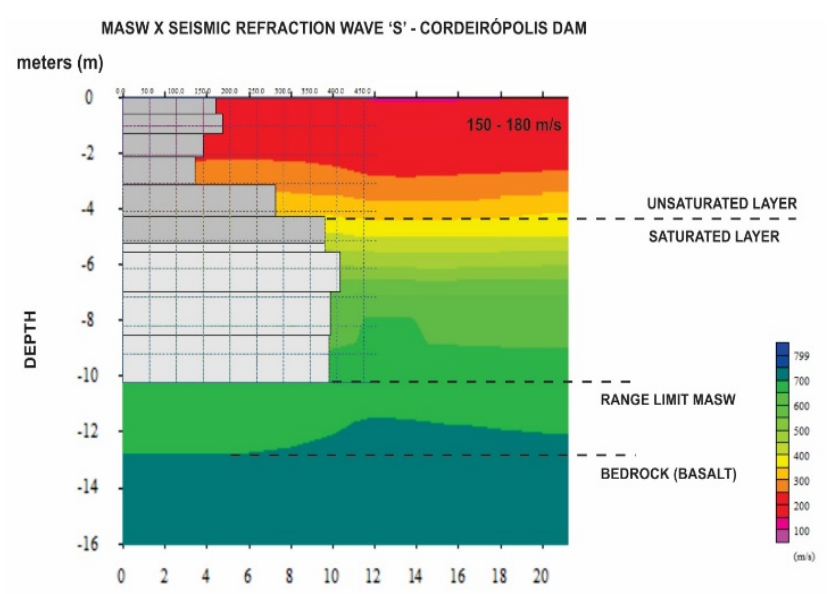

Figure 10 - Analysis of the first 20 meters of section 2D of S-wave seismic refraction comparing with the values obtained by the MASW method at the dam located in Cordeirópolis - São Paulo. 


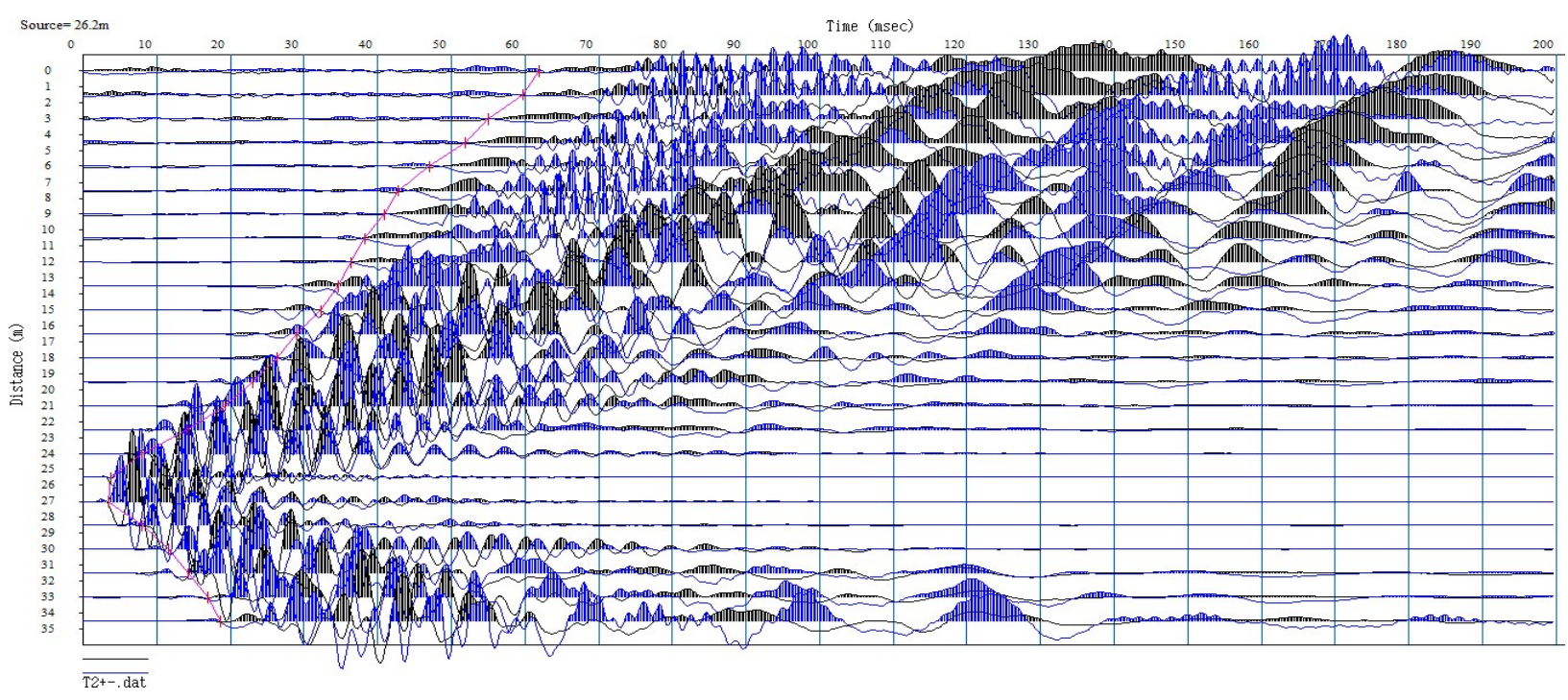

Figure 11 - Seismogram with the S-wave register (marked with the pink line) obtained with shot 2 in the 26 meters position of base 1.

Before the study was carried out, we had the knowledge about the material that composed the body of the dam which were soil of alteration of basic rocks (basalts) compacted. So, it was expected to find a material with slightly smaller Swave velocities in the more superficial regions and higher values when it reached the rockfilled top, which in this case would be composed of basalt blocks, characteristic of the Serra Geral Formation.

The first analysis on the behavior of the S-wave that could occur in the dam body, including being one of the reasons for the execution of the study, would be on regions indicating lower values of seismic wave propagation velocity, these spots could indicate possible regions where the material could be poorly compacted. This may be due to a compaction difference in the material of the dam body, in the construction step or during the operation resulting from the flow of large vehicles in the crest of the structure.

The interpretations of the results were proposed according to studies in the areas, which are well known and geologically mapped by researchers. Studies, such as those by Brandes et al. (2011), carried out using the same lithologies as in the present study, which obtained similar results and interpretations of seismic wave velocities, were also considered.

Figure 8 shows the propagation velocity in a section of the area. It is possible to perceive two pink spots on the 30meter and 72-meter points, with S-wave velocity values less than $100 \mathrm{~m} / \mathrm{s}$, identifying possible areas of weakness where the material would be badly compacted.

Another very clear point in the refraction section is the gradual but very remarkable change in the increase of the S-wave velocity at the depth of approximately 4.5 meters.

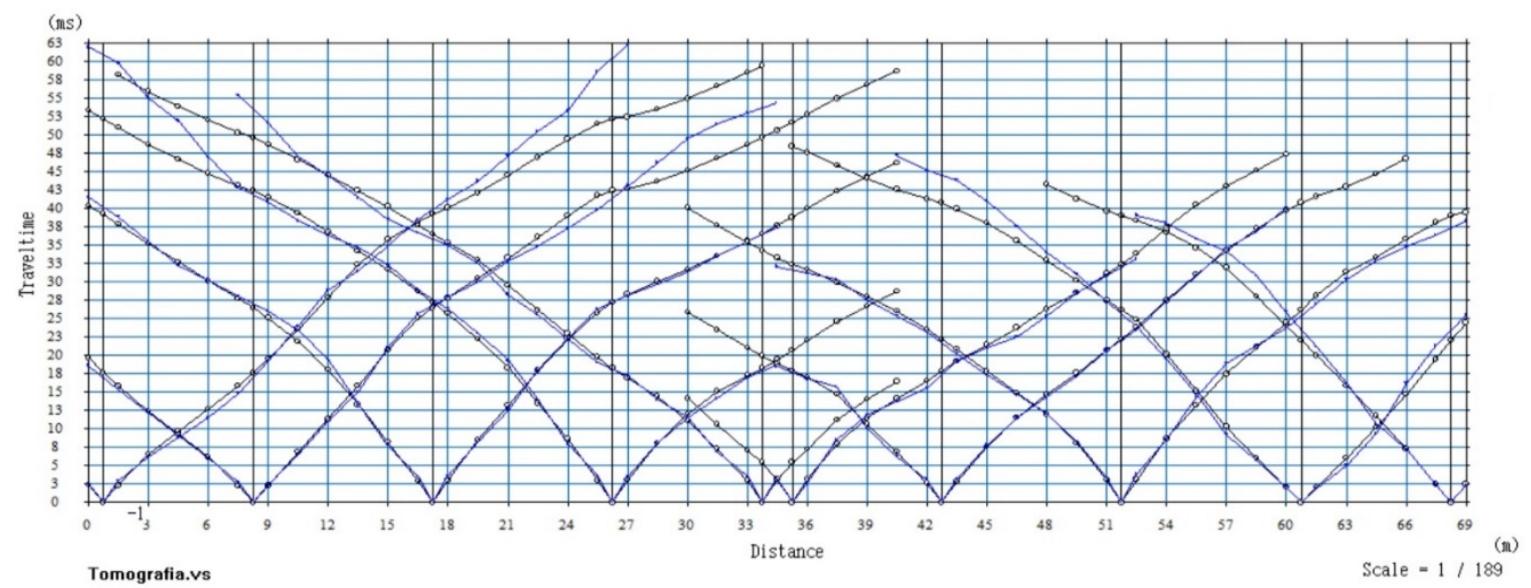

Figure 12 - Time curve $x$ distance of the shots performed in the line of seismic acquisition of S-wave refraction in the dam located in Ipeúna - São Paulo. 
Such change occurs because at this point the rockfilled top was reached, and it is, as mentioned before, composed mostly of basalt blocks altered. The depth of 12 meters was established as a possible beginning of the presence of the rockfilled top, due to the increase in the values of $\mathrm{Vs}$ at this level. However, the Vs value were not as high according to what is expected for a basalt with little weathering action, according to data from Dias (2011), for example. Therefore, it is believed that it is an area with strong alteration of this basic rock.

The 2D refraction section of the S-wave of the dam found in the city of Cordeirópolis - São Paulo displays an anomaly between the points of 42 and 46 meters in the depth from 2 meters. It happens as a result from the presence of the concrete spillway of the dam in that point, which evidences the efficiency of the method in the investigation of important components of the subsurface of the dam structure, such as spillways and depth of the rockfilled top. The method is also thoroughly efficient in displaying characteristics for analysis of the physical integrity of the structure, such as problems in compacting the material in homogeneous dams, for example.

The extraction of the dispersion curve proved itself very difficult. The best result was with offset from base 1 and 16 meters away (Fig. 9). The generated curve causes certain difficulty in reading, since it can be either a first higher mode or the fundamental mode. After the inversion process, a Swave velocity profile was generated in depth (as a gray column chart), shown below in Figure 10.

It is paramount to mention that the dispersion curve extraction step is quite delicate, and the process is highly dependent on the experience of the person interpreting the data, this does not mean that the data is poor quality. Misinterpretation may compromise the entire outcome of the work. Poor quality data generates dispersion images which are not possible to extract the curve of dispersion. In none of the data acquisitions in the present study did this happened.

The positive point is that during the data acquisition process it was already possible to perform "primary data processing" and to view the dispersion images being generated, thus facilitating a first selection of quality data. And in the case of bad dispersion images, it was already possible to change the arrangement or the offset points, for example.

The first point that draws attention is the similarity between the S-wave velocity section derived from the seismic refraction data and the velocity profile derived from the MASW data. The velocities are quite close, varying between 150 and $180 \mathrm{~m} / \mathrm{s}$. The results of both methods were compared in Figure 10.

Lastly, another very clear point is that the S-wave velocity changes when the rockfilled top is found. Consistent with the refraction seismic data, the MASW data also gets a velocity increase (to $375 \mathrm{~m} / \mathrm{s}$ ) at 4.2 meters deep.

\section{IPEÚNA DAM}

Since the areas of study have different lithologies (sedimentary rocks $\mathrm{x}$ volcanic rocks), some changes in data quality were expected. In this case, one of the objectives of the research was to try to identify in which situation the operation of the MASW seismic method obtained better quality data.

In Figure 11, we have the seismogram of the acquisition line at the 26-meter shooting position, with the first picked

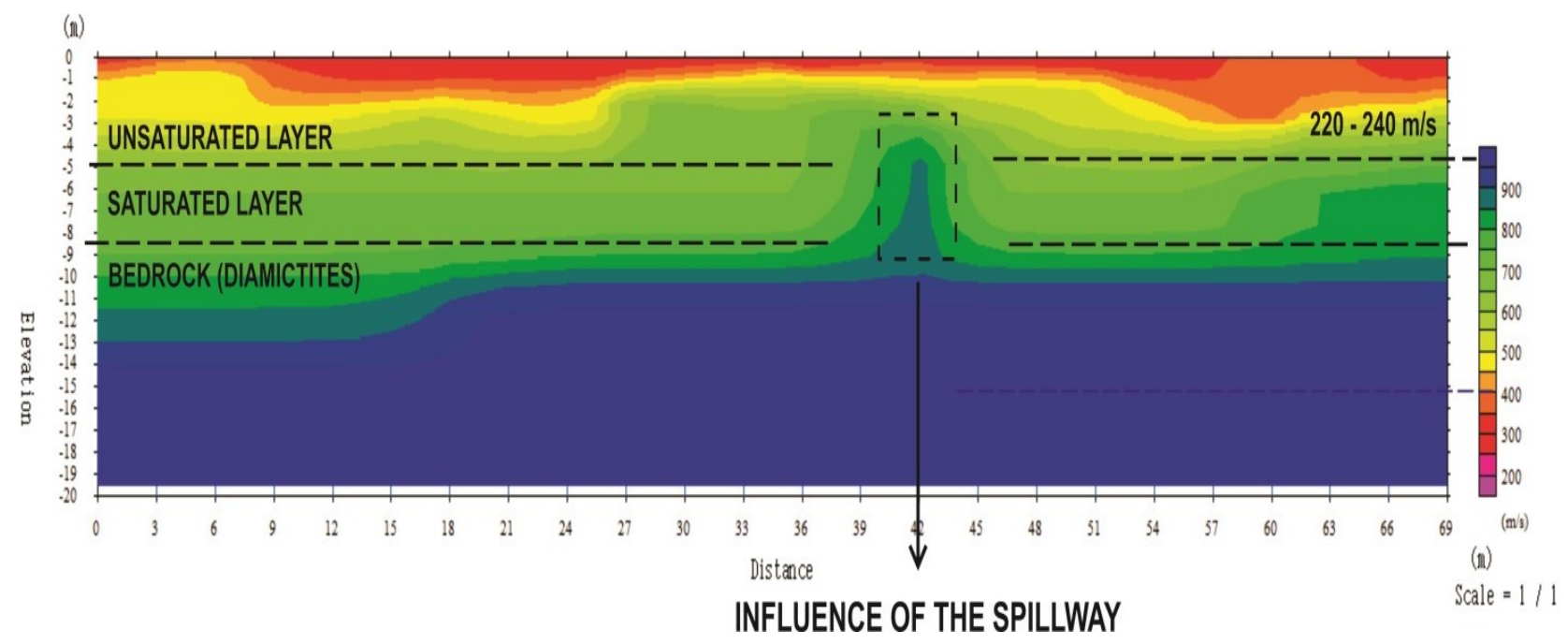

Figure 13 - 2D S-wave velocity section obtained by tomographic inversion in Ipeúna - São Paulo. 


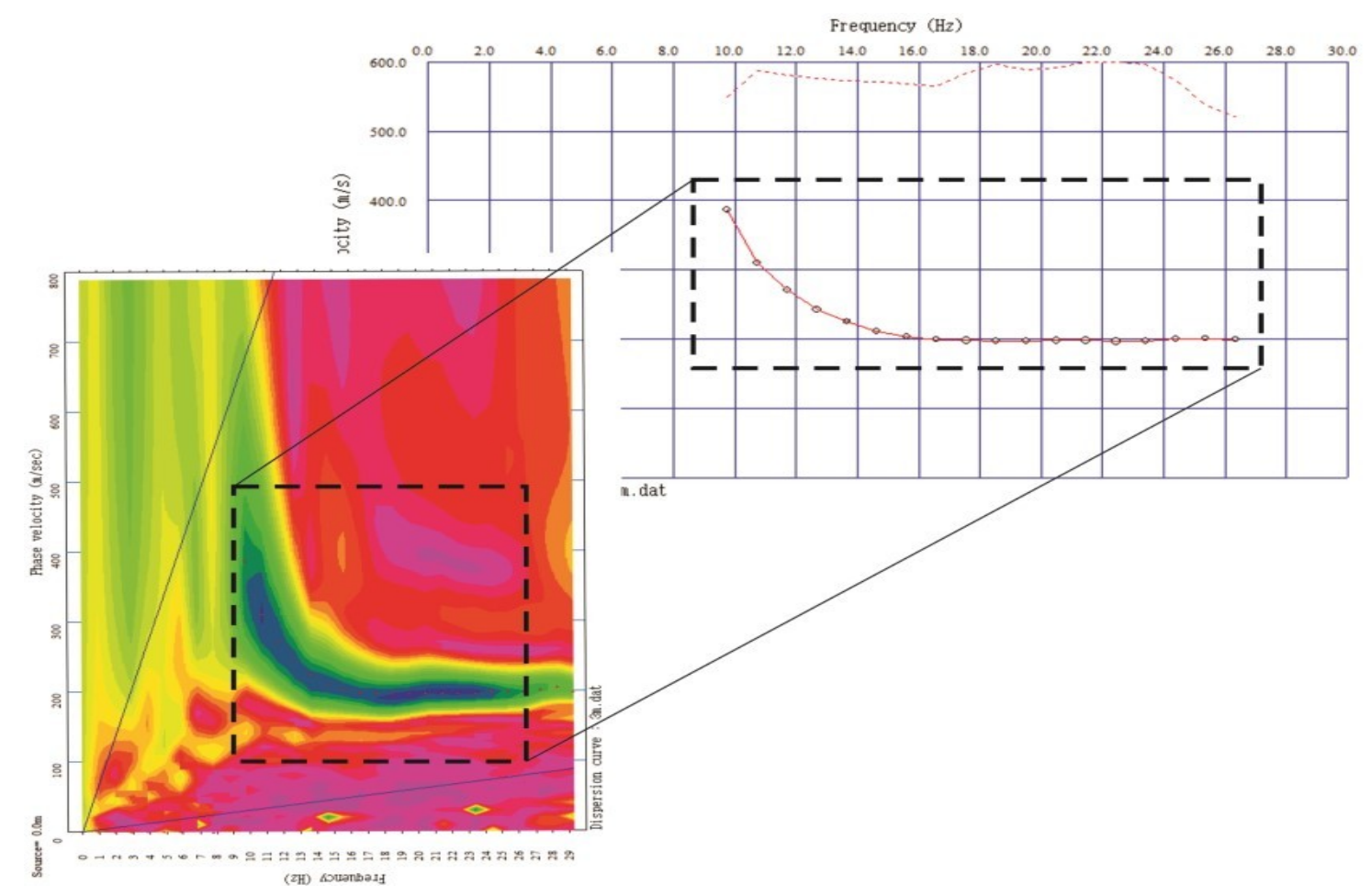

Figure 14 - Dispersion image obtained from the MASW data and the extracted dispersion curve (3-meter of minimum offset).

breaks of the refracted S-waves (pink line). The first breaks picked from all the seismograms resulted in the graphs time $x$ distance showed in Figure 12.

The S-wave velocity profile in the Ipeúna dam presents, for the near surface, higher values than the Cordeirópolis ones (between $300-350 \mathrm{~m} / \mathrm{s}$ ), probably because it is very compacted. It does not present regions with low values of Vs (possible indicative of poor compaction) (Fig. 13). The dam is inserted in an area with considerable flow of vehicles, situation which helps in the process of compaction.

Another difference between the results of the two dams refers to the level of the saturated / unsaturated zone. In the dam located in Ipeúna, the level of the saturated zone was established at approximately 5 meters referring to the Swave velocity (Vs) of $550 \mathrm{~m} / \mathrm{s}$. This difference in Vs can be explained due to the different lithologies and degrees of compaction of the material in the dam's bodies. In the dam located in Ipeúna, the material was more compacted, therefore it was expected to find higher values of Vs in this area.

The analysis that we highlight is the one referred on the point of 42 meters, where there is an anomaly from the depth of 3 meters to, approximately, 8 meters. Precisely in this region, the spillway of the dam cuts its body transversely. As well as in the dam located in Cordeirópolis - São Paulo, the presence of spillways resulted in interference in the velocity of the S-wave, being even possible to trace the spillway depth in the case of the

\section{Cordeirópolis.}

Another observation refers to the depth of approximately 9 meters, where the S-wave velocities increase to values of $900 \mathrm{~m} / \mathrm{s}$, probably due to the presence of the bedrock. It is worth highlighting the difference of the S-wave velocity values among the dams, justifying the choice of distinct lithologies to perform the methods and to better understand the S-wave behavior in volcanic rocks $x$ sedimentary rocks.

The velocity of wave $S(V s)$ at the Ipeúna dam are higher than those obtained at the Cordeirópolis dam due to the lithological composition. While in Cordeirópolis dam the material is basically basic rock alteration soil, in the Ipeúna dam the material used is siltstone, this explains the differences in values.

Upon analyzing the results of the MASW method in the dam located in Ipeúna, the best quality dispersion images were obtained employing 3- and 6-meter of minimum offset, however in the frequencies from $10 \mathrm{~Hz}$ it became difficult to precisely trace the dispersion curve (Fig. 14).

The first point that is highlighted is the decrease of Vs near the depth of 3 meters. Since it is an unusual behavior, the processing was carried out in two different softwares (Geopsy and Seislmager) in order to solve the doubts regarding a possible data processing problem. However, the same result was found in both processes. Therefore, the issue is believed to be related to the material that is more fragmented and has a lower degree of compaction at this location. 


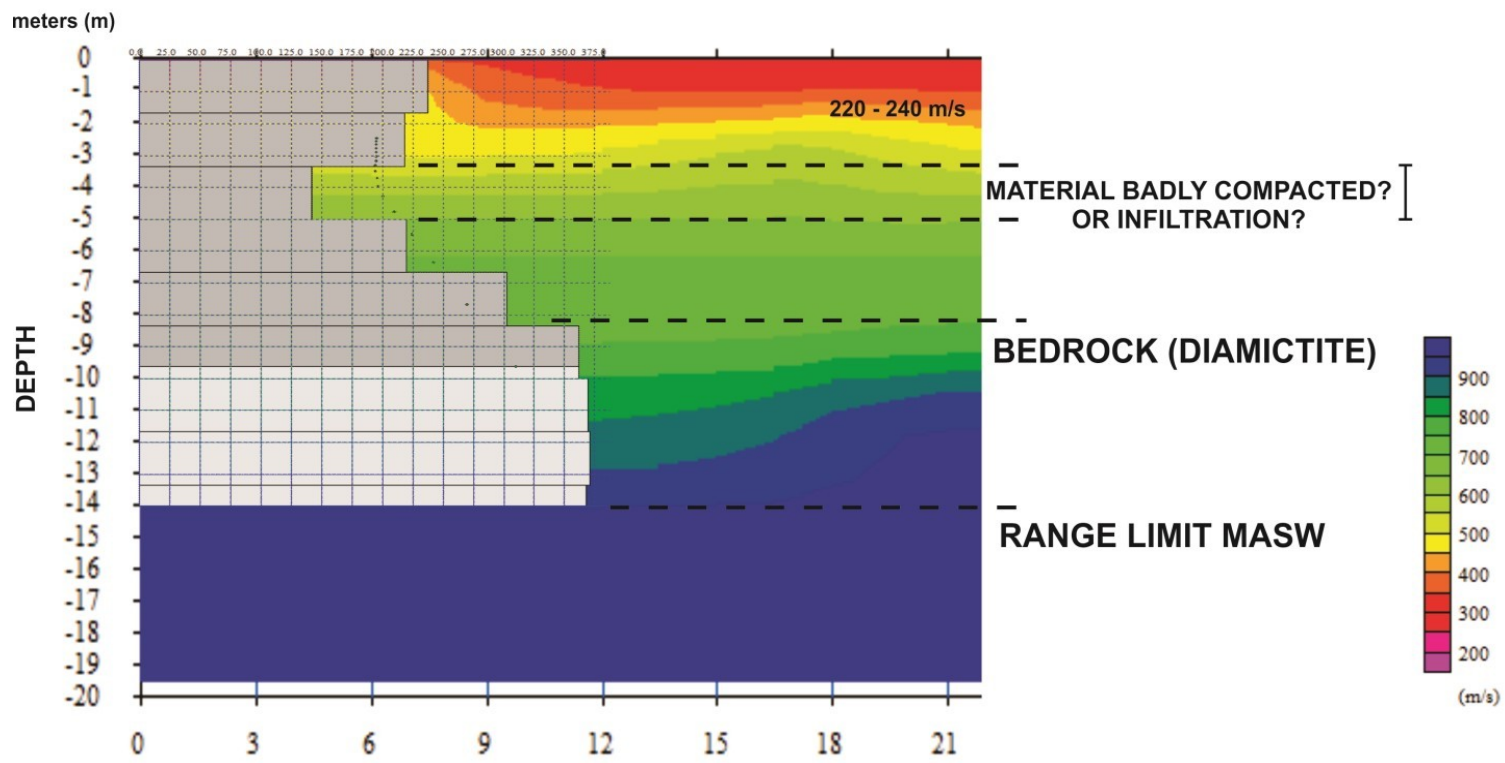

Figure 15 - Analysis of the first 20 meters of 2D S-wave refraction seismic section comparing with the values obtained by the MASW method in the dam located in Ipeúna-São Paulo.

The depth of 7 and 8 meters shows an increase of Vs up to $375 \mathrm{~m} / \mathrm{s}$, quite compatible with the values found by the seismic refraction method. Both results were illustrated in the same image to better present the data (Fig. 15).

Finally, comparing the behavior of the application of the MASW method in the two dams, one can perceive a greater depth in the dam in Ipeúna. It is believed that better compaction of the material of the dam body has aided in better penetration of the S-wave in deeper layers.

\section{CONCLUSIONS}

The recent cases of bursts on tailings dams in Brazil have drawn a lot of attention because of the power of destruction, causing irreparable social, human and environmental damages. Thus, the need to develop new techniques or use several methods together in order to improve the understanding of the behavior of the dams and raise the levels of safety of the work is very clear.

For that reason, the development of this project in small dams is crucial, since the use of associated geophysical methods culminated in a very satisfactory result, determining the depth of the bedrock and also recording possible zones of bad compaction of the material that composes the body of the dam and the delimitation of layers of different lithologies.

The use of the MASW method in dams is not very common in Brazil, so the work becomes important since it shows that it is possible to obtain data about the dam body through the use of the method. It is also worth noting that the study is aimed at small earth dams, that is, with small depths of investigation, making the MASW method viable. In other circumstances, where more depth of research is needed, the method would not be the best option.

Due to the fact that it is a study in an area which didn't have the data of the construction project of the dam, the work gains prominence, since it will be essential in the cases of abandoned dams or with data shortages, these being often the reality of some dams in Brazil. Another interesting point about the application of the MASW method and the seismic refraction, and also from obtaining the subsurface S-wave velocity prior to the dam installation is the dynamic stiffness module ( $\left.G_{\text {máx }}\right)$ provided by the data of $V s$ and soil density, being it a fundamental parameter for a work of this type (Park \& Kishida, 2018).

Another advantage of the joint interaction of both seismic methods relates to the arrangement. Since they have the same arrangement, it facilitates field data acquisition, requiring only the change in seismic wave generation, since the multichannel method uses surface 
waves while the S-wave uses seismic refraction.

The seismic methods of MASW and S-wave data refraction in this work can be associated with data of electroresistivity, self-potential (SP) and ground penetrating radar (GPR), for example, to obtain a more detailed understanding of the dam behavior, defining a presence of zones of weakness and water percolation areas.

\section{ACKNOWLEDGMENTS}

The authors thank the Fundação de Amparo à Pesquisa do Estado de São Paulo - FAPESP (Grant 2016/18080-9) for its financial support. The authors also thank the Center for Infrastructure Construction Technology (CT-OBRAS) of the Institute for Technological Research (IPT) in particular the Group of Geophysics for the support of equipment and infrastructure.

\section{REFERENCES}

BRANDES HG, ROBERTSON IN \& JOHNSON GP. 2011. Soil and Rock Properties in a Young Volcanic Deposit on the Island of Hawaii. Journal of Geotechnical and Geoenvironmental Engineering, 137(6): 597-610. doi: 10.1061/(ASCE)GT.1943-5606.0000453.

BRETAS EM, LÉGER P, LEMOS JV, LOURENÇO PB \& RAMOS JM. 2010. Análise e Reforço de Barragens Gravidade. In: Encontro Nacional sobre Conservação e Reabilitação de Estruturas. APEE, Lisbon, Portugal. 11 pp.

CAMARERO PL \& MOREIRA CA. 2017. Geophysical investigation of earth dam using the Electrical Tomography Technique. REM: Int. Eng. J., 70(1): 47-52.

CULLEN AH. 1964. Rios Prisioneiros: A História das Barragens. Belo Horizonte: Editora Itatiaia Limitada de Belo Horizonte, Brazil. 202 pp.

DIAS FL. 2011. Estudo da Camada de Basalto em Bebedouro, Bacia do Paraná, com Função do Receptor Implicações para a Sismicidade Induzida por Poços Profundos. Master Dissertation, IAG-USP, Universidade de São Paulo, SP, Brazil. doi: 10.11606/D.14.2019.tde12062018-172635. 121 pp.

DUARTE AP. 2008. Classificação das barragens de contenção de rejeitos de mineração e de resíduos industriais no Estado de Minas Gerais em relação ao potencial de risco. Master Dissertation, Universidade Federal de Minas Gerais, MG, Brazil.132 pp.

DUTTA NP. 1984. Seismic Refraction Method to Study the Foundation Rock of a Dam. Journal of Geophysical Prospecting, 32: 1103-1110.

EIKMEIER C. 2014. Emprego do método MASW (Multichannel Analysis of Surface Waves) em área urbana: um estudo na cidade de São Paulo. Trabalho de Conclusão de Curso - Instituto de Astronomia, Geofísica e Ciências Atmosféricas, Universidade de São Paulo, SP, Brazil. 132 pp.

FOTI S. 2000. Multistation Methods for Geotechnical Characterization using Surface Waves. PhD Thesis, Politecnico di Torino, Italy. 229 pp.

GANDOLFO OCB. 2011. Ensaios sísmicos (refração utilizando ondas $\mathrm{P}$ e $\mathrm{S}$ e ensaio com ondas superficiais) na caracterização geotécnica de um aterro. In: 12th International Congress of the Brazilian Geophysical Society. Expanded Abstracts. SBGf, Rio de Janeiro, Brazil. CDROM.

GOOGLE EARTH. 2019. Maps. Available on: <http://earth.google.com/web>. Access on: Jan. 10, 2019.

GUIRELI NETTO L, GANDOLFO OCB, MALAGUTTI FILHO W \& DOURADO JC. 2019. Integração dos métodos de sísmica de refração de ondas e análise multicanal de ondas superficiais (MASW) em barragem de terra. In: 16th International Congress of the Brazilian Geophysical Society. Expanded Abstracts. SBGf, Rio de Janeiro, Brazil. CDROM.

GUIRELI NETTO L, MALAGUTTI FILHO W \& GANDOLFO OCB. 2020. Detection of seepage paths in small earth dams using the self-potential method (SP). REM - International Engineering Journal, 73(3): 303-310. DOI: 10.1590/037044672018730168.

HERZIG RL. 2003. Integração das técnicas de refração e reflexão sísmica rasa aplicada aos estudos de barragens UHE Piraju II. Master Dissertation. Instituto de Astronomia Geofísica e Ciências Atmosféricas, Universidade de São Paulo, SP, Brazil. 167 pp.

IBAMA - INSTITUTO BRASILEIRO DO MEIO AMBIENTE E DOS RECURSOS NATURAIS RENOVÁVEIS. 2015. Laudo Técnico Preliminar: Impactos ambientais decorrentes do desastre envolvendo o rompimento da barragem de Fundão, em Mariana, Minas Gerais. Coordenação Geral de Emergências Ambientais - CGEMA. Brasilia, DF, Brazil. 
ICOLD - INTERNATIONAL COMMISSION ON LARGE DAMS. 1995. Dam Failures Statistical Analysis. Bulletin 99. International Commission on Large Dams. Paris, France.

KARRAY M, LEFEBVRE G, ETHIER Y \& BIGRAS A. 2010. Assessment of deep compaction of the Péribonka dam foundation using "modal analysis of surface waves" (MASW). Canadian Geotechnical Journal, 47(3): 312-326.

LOU WC. 1981. Mathematical Modeling of Earth Dam Breaches. Doctorate Thesis on Engineering. Colorado State University. Fort Collins. Colorado, USA.

MORENGHI CL. 2007. Arcabouço estratigráfico e potencial de armazenamento em arenitos permocarboníferos do Grupo Itararé na região do Alto Estrutural de Pitanga, centro-leste do Estado de São Paulo. Master Dissertation, Instituto de Geociências, Universidade de São Paulo, SP, Brazil. 105 pp. doi: 10.11606/D.44.2007.tde-27082007105209.

PARK D \& KISHIDA T. 2018. Shear wave velocity profiles of fill dams. Soil Dynamics and Earthquake Engineering, 104: 250-258.

PASQUET S, BODET L, DHEMAIED A, MOUHRI A, VITALE Q, REJIBA F, FLIPO N \& GUÉRIN R. 2015. Detecting different water table levels in a shallow aquifer with combined P-, surface and SH-wave surveys: insights from $V_{P} N_{S}$ or Poisson's ratios. Journal of Applied Geophysics, 113: 38-50.

RANKINE WJM \& MILLAR WJ. 1898. A Manual of Applied Mechanics. 15th ed., London: C. Griffin and Co., Limited. $676 \mathrm{pp}$.
SEIMETZ EX. 2012. Estudos geofísicos ao longo do futuro trecho norte do metrô de Brasília. 2012. Master Dissertation (Geociências Aplicadas), Universidade de Brasília, Brasília, Brazil. xix, 97 pp, il.

TAIOLI F. 1999. Avaliação de propriedades elásticas dinâmicas de materiais geológicos da RMSP. Doctorate Thesis (Livre Docência em Geologia Ambiental), Instituto de Geociências, Universidade de São Paulo, São Paulo, Brazil. doi: 10.11606/T.44.2013.tde-31102013-181117. 87 pp.

TEIXEIRA WLE. 2013. Um estudo das condições de percolação e estabilidade em barragens de terra mediante métodos geofísicos: caso do dique de Sant Llorenç de Montgai - Espanha. Doctorate Thesis (Geodinâmica, Geofísica), Universidade Federal do Rio Grande do Norte, Natal, Brazil. 188 pp.

TURESSON A. 2007. A comparison of methods for the analysis of compressional, shear, and surface wave seismic data, and determination of the shear modulus. Journal of Applied Geophysics, 61(2): 83-90.

XIA J, MILLER R, PARK C, HUNTER J \& HARRIS J. 2000. Comparing Shear-Wave Velocity Profiles from MASW with Borehole Measurements in Unconsolidated Sediments, Fraser River Delta, B.C., Canada. Journal of Environmental and Engineering Geophysics, 5(3): 1-13.

ZAINE JE. 1994. Geologia da Formação Rio Claro na folha Rio Claro (SP). Master Dissertation. Universidade Estadual Paulista, Rio Claro, SP, Brazil. 98 pp. 